\title{
Peningkatan Keterampilan Mengubah Teks Wawancara Menjadi Narasi Menggunakan Model Kooperatif Tipe Think Talk Write Pada Siswa Kelas VII B SMP Negeri 11 Singkawang
}

\author{
Mardian $^{1)}$, Suyatno ${ }^{2)}$ \\ 1) STKIP Singkawang, Singkawang, Indonesia \\ E-mail: mardiandeeza@gmail.com \\ ${ }^{2)}$ STKIP Singkawnag, Jl. STKIP Kelurahan Naram, Singkawang, Indonesia \\ E-mail: suyatttno@gmail.com
}

\begin{abstract}
Abstrak. Tujuan umum dalam penelitian ini adalah untuk mendeskripsikan peningkatkan keterampilan mengubah teks wawancara menjadi narasi menggunakan model kooperatif tipe think talk write pada siswa kelas VII B SMP Negeri 11 Singkawang yang meliputi perencanaan, pelaksanaan, dan hasil yang dicapai. Penelitian ini merupakan penelitian kualitatif, dengan menggunaan metode kualitatif deskripsif. Rancangan penelitian ini yaitu penelitian tindakan kelas (PTK). Data penelitian berupa proses pembelajaran mengubah teks wawancara menjadi narasi dan hasil belajar siswa dengan menerapkan model pembelajaran kooperatif tipe think talk write. Teknik pengumpulan data menggunakan pengukuran (tes), observasi, dan dokomentasi. Hasil penelitian menunjukan bahwa penerapan model kooperatif tipe think talk write dapat meningkatkan keterampilan mengubah teks wawancara menjadi narasi siswa kelas VIIB SMP Negeri 11 Singkawang. Hal ini dibuktikan dengan peningkatan kemampuan guru dalam mengelola pembelajaran, dan kegiatan partisipasi siswa dalam mengikuti proses pembealajaran. Kinerja guru dalam melaksanakan pembelajaran terus meningkat dari $78,77 \%$ pada siklus 1 menjadi $88,63 \%$ pada siklus 2 . Nilai sikap siswa di kelas mengikuti proses pembelajaran pada siklus 1 mencapai 77,24\% meningkat menjadi 86,37\% pada siklus 2 . Nilai aktiviatas siswa di kelas mengikuti proses pembelajaran pada siklus 1 mencapai $77,49 \%$ meningkat menjadi $87,81 \%$ pada siklus 2 . Hasil pembelajaran dengan menggunakan model kooperatif tipe think talk write mengalami peningkatan, hal ini dapat diketahui setelah membandingkan hasil pratindakan, siklus 1, dan siklus 2. Nilai rata-rata siswa pratindakan adalah 57,03 berada dalam kategori cukup, pada siklus 1 rata-rata nilai 72,5 dalam kategori baik, dan pada siklus 2 nilai rata-rata 85,62 berada dalam kategori sangat baik. Dari hasil tersebut dapat disimpulkan bahwa penerapan model pembelajaran kooperatif tipe think talk write dalam penelitian tindakan kelas dapat meningkatkan kualitas proses pembelajaran mengubah teks wawancara menjadi narasi.
\end{abstract}

Kata Kunci: menulis, teks wawancara, kooperatif tipe think talk write.

\section{PENDAHULUAN}

Pendidikan merupakan wahana yang sangat penting dan merupakan modal utama yang harus ditingkatkan dalam rangka melaksanakan pembangunan suatu negara. Kegiatan pendidikan tidak bisa diabaikan karena masa depan bangsa ditentukan oleh mutu pendidikan suatu bangsa itu sendiri. Mutu pendidikan banyak bergantung pada mutu guru khususnya dalam proses pembelajaran. Satu di antara aspek berbahasa yang diajarkan di sekolah yaitu keterampilan menulis. [10] menyatakan bahwa "Menulis merupakan suatu keterampilan berbahasa yang dipergunakan untuk berkomunikasi secara tidak langsung, tidak secara tatap muka dengan orang lain.” Kegiatan menulis, khususnya mengubah teks wawancara menjadi narasi dalam dunia pendidikan termasuk dalam aktivitas pembelajaran. Hal ini tercantum dalam Kurikulum Tingkat Satuan Pendidikan
(KTSP) dengan Standar Kompetensi (SK) Menulis 12. Mengungkapkan berbagai informasi dalam bentuk narasi dan pesan singkat (KD) 12.1 Mengubah teks wawancara menjadi narasi dengan memperhatikan cara penulisan kalimat langsung dan tak langsung.

Berdasarkan observasi prariset yang dilakukan di SMP Negeri 11Singkawang, dengan guru bahasa Indonesia Paulina Gai Nana, S.Pd., beliau menyatakan bahwa kemampuan siswa dalam menulis sangat kurang, hal ini berkaitan dengan motivasi siswa yang rendah sehingga berpengaruh terhadap hasil belajar siswa khususnya dalam hal menulis. Kemudian dari sisi guru yang berkaitan dengan pemilihan model pembelajaran yang kurang tepat, sehingga mempengaruhi keberhasilan proses pembelajaran. Kedua faktor tersebutlah yang mempengaruhi proses pembelajaran yang dilakukan di kelas. Penggunaan model pembelajaran yang kurang tepat akan mempengaruhi proses pembelajaran 
dikelas yang akhirnya mempengaruhi hasil menulis siswa yang dimana siswa kurang termotivasi untuk mengikuti pembelajaran, dan siswa masih kesulitan untuk mengembangkan ide-ide ataupun gagasan yang dimilikinya dalam bentuk sebuah tulisan.Hal ini dapat terlihat dari hasil menulis siswa di SMP Negeri 11 Singkawang pada semester I, bahwa hasil belajar siswa dalam menulis pada kelas VII A mencapai ketuntasan 54,5\% dari 33 siswa, yang berarti 18 siswa tuntas sedangkan 15 siswa belum tuntas, kelas VII B $40,62 \%$ dari 32 siswa, yang berarti 13 siswa tuntas sedangkan 19 siswa belum tuntas dari nilai kriteria ketuntasan minimum yang ditentukan sekolah yaitu 75. Jika dilihat dari hasil belajar siswa pada tiap kelas maka kelas VII B merupakan kelas yang terendah dalam pencapaian hasil belajar. Oleh karena itu, kegagalan yang berwujud rendahnya hasil belajar menulis dipengaruhi oleh faktor tertentu, seperti masih kurangnya hasil belajar kognitif siswa dalam aspek menulis, kurangnya minat/motivasi siswa dalam pembelajaran menulis, siswa masihkesulitan untuk mengembangkan ide-idenya ketika mendapat tugas menulis, dan masih kurangnya penerapan model pembelajaran dalam proses pembelajaran. Oleh karena itu, penulis memilih model kooperatif tipe think talk write untuk diterapkan di kelas VII B sebagai model pembelajaran untuk meningkatkan hasil belajar siswa pada materi mengubah teks wawancara menjadi narasi.

Berdasarkan identifikasi masalah penelitian di atas maka masalah dalam penelitian ini adalah "Bagaimanakah Peningkatkan Keterampilan Mengubah Teks Wawancara Menjadi Narasi Menggunakan Model Kooperatif Tipe Think Talk Write Pada Siswa Kelas VII B SMP Negeri 11 Singkawang?". Adapun sub-sub masalah yang dapat dirumuskandalam penelitian ini adalah: (1) bagaimanakah perencanaan pembelajaran keterampilan mengubah teks wawancara menjadi narasi menggunakan model kooperatif tipe think talk write pada siswa kelas VII B SMP Negeri 11 Singkawang?; (2) bagaimanakah pelaksanaan pembelajaran keterampilan mengubah teks wawancara menjadi narasi menggunakan model kooperatif tipe think talk write pada siswa kelas VII B SMP Negeri 11 Singkawang?; (3) bagaimanakah hasil pembelajaran keterampilan mengubah teks wawancara menjadi narasi menggunakan model kooperatif tipe think talk write pada siswa kelas VII B SMP Negeri 11Singkawang?. Tujuan umum dalam penelitian ini adalah untuk mendeskripsikan peningkatkan keterampilan mengubah teks wawancara menjadi narasi menggunakan model kooperatif tipe think talk write pada siswa kelas VII B SMP Negeri 11 Singkawang. Adapun tujuan khususnya adalah: (1) mendeskripsikan perencanaan pembelajaran mengubah teks wawancara menjadi narasi menggunakan model kooperatif tipe think talk write pada siswa kelas VII B SMP Negeri 11 Singkawang; (2) mendeskripsikan pelaksanaan pembelajaran mengubah teks wawancara menjadi narasi menggunakan model kooperatif tipe think talk write pada siswa kelas VII B SMP Negeri 11 Singkawang; (3) mendeskripsikan hasil pembelajaran keterampilan mengubah teks wawancara menjadi narasi menggunakan model kooperatif tipe think talk write pada siswa kelas VII B SMP Negeri 11 Singkawang tahun ajaran 2015/2016. Keterampilan menulis merupakan salah satu dari empat keterampilan berbahasa yang mempunyai peranan penting dalam kehidupan manusia. Menulis adalah menurunkan atau melukiskan lambang-lambang grafik yang menggambarkan suatu bahasa yang dipahami seseorang, sehingga orang lain dapat membaca lambang-lambang grafik tersebut jika mereka memahami bahasa dan gambaran grafik tersebut [10]. Menulis adalah menuangkan ide ke dalam suatu bentuk visual [1] . Menulis adalah kegiatan melahirkan pikiran dan perasaan dengan tulisan. Dapat juga diartikan bahwa menulis adalah berkomunikasi mengungkapkan pikiran, perasaan, dan kehendak kepada orang lain secara tertulis [9].

Senada dengan pendapat [8] menyatakan bahwa "Menulis adalah mengomunikasikan apa dan bagaimana pikiran penulis". Kegitan menulis dapat melatih kemampuan bepikir siswa, diantaranya adalah mengubah teks wawancara menjadi narasi. Menurut [7] Narasi merupakan suatu bentuk wacana yang berusaha mengisahkan suatu kejadian atau peristiwa sehingga tampak seolah-olah pembaca melihat atau mengalami sendiri peristiwa itu. Secara singkat [2] juga berpendapat tentang pengertian narasi yaitu suatu corak karangan atau wacana yang mengisahkan atau menceritakan suatu peristiwa atau kejadian dalam suatu waktu [3] "Menarasikan teks wawancara dapat diartikan suatu kegiatan memaparkan dialog dalam bentuk tulisan."Pembelajaran kooperatif mengacu pada model pembelajaran dimana siswa bekerja sama dalam kelompok kecil dan saling membantu dalam belajar [5]. Model pembelajaran kooperatif tipe think talk write adalah pada dasarnya dibangun melalui berpikir, berbicara, dan menulis [6]. Berdasarkan pemaran di atas peneliti tertarik untuk melakukan penelitian tindakan kelas dengan materi yang akan dikaji yaitu mengubah teks wawancara menjadi narasi menggunakan model kooperatif tipe think talk write. Model yang digunakan diharapkan dapat memperbaiki masalah yang terdapat dalam pembelajaran menulis pada siswa kelas VIIB SMP Negeri 11 Singkawang.

\section{METODE}

Rancangan penelitian ini menggunakan PenelitianTindakanKelas (PTK). [4] menyatakan bahwa penelitian tindakan kelas adalah "Sebagai suatu bentuk penelitian yang bersifat reflektif dengan melakukan tindakan-tindakan tertentu dengan tujuan memperbaiki atau meningkatkan praktek-praktek [sic!] pembelajaran di kelas secara lebih profesional." Tempat atau lokasi penelitian tindakan kelas ini SMP Negeri 11 Singkawang untuk mata pelajaran bahasa Indonesia kelas VII B. Kelas yang menjadi objek penelitian ini yaitu kelas VII B yang berjumlah 32 siswa terdiri dari 14 siswa laki-laki dan 18 siswa perempuan.

Kolaborator dalam penelitian ini adalah guru mata pelajaran bahasa Indonesia yang mengajar di kelas VII B yang bernama Paulina Gai Nana, S.Pd. Metode dalam penelitian ini menggunakan metode deskriptif. Sumber data dalam penelitian ini adalah guru dan siswa. Adapun data yang diperoleh dalam penelitian ini adalah penilaian proses 
dan hasil. Teknik pengumpul data merupakan suatu cara yang dilakukan peneliti untuk memperoleh data. Tanpa mengetahui teknik pengumpul data, maka peneliti tidak akan mendapatkan data yang memenuhi standar data yang di terapkan". Untuk memperoleh data dalam penelitian ini, peneliti menggunakan teknik pengumpul sebagai berikut. (1) teknik observasi langsung, (2) teknik pengukuran, (3) teknik dokumentasi. Alat pengumpul data yang digunakan dalam penelitian ini adalah lembar observasi APKG 1, APKG 2, lembar pengamatan aktivitas, lembar pengamatan sikap dan tes.

Teknik analisis data yang digunakan dalam rencana penelitian ini yaitu perencanaan dinilai menggunakan APKG 1, pelaksanaan dinilai menggunakan APKG 2, dan hasil pembelajaran dianalisis dengan melakukan penilaian proses dan hasil.

\section{HASIL DAN PEMBAHASAN}

HASIL

Penelitian tindakan kelas ini telah dilakukan dalam dua siklus. Melalui dua siklus tersebut telah didapat beberapa fakta berkaitan dengan "Peningkatan Keterampilan Mengubah Teks Wawancara Menjadi Narasi Menggunakan Model Kooperatif Tipe Think Talk Write pada Siswa Kelas VII B SMP Negeri 11 Singkawang”. Fakta-fakta tersebut berkaitan dengan proses dan hasil belajar siswa dalam mengubah teks wawancara menjadi narasi menggunakan model kooperatif tipe think talk write. Berikut ini akan dibahas hal-hal yang berkaitan dengan hasil penelitian secara jelas. Hal-hal tersebut meliputi peningkatan kualitas proses, hasil, dan respon sikap siswa terhadap pembelajaran mengubah teks wawancara menjadi narasi dengan model think talk write. Pembahasan ini diharapkan dapat menggambarkan secara umum hasil penelitian tindakan kelas ini.Pelaksanaan penelitian tindakan kelas dalam setiap siklus mencakup empat tahap, yakni perencanaan, pelaksanaan tindakan, observasi, dan refleksi. Berikut ini adalah uraian proses pelaksanaan penelitian tindakan kelas pada setiap siklus.

\section{Perencanaan (planning)}

Perencanaan siklus 1 dilaksanakan pada hari Selasa, 5 April 2016 dan siklus 2 dilaksanakan pada hari jumat 22 April 2016. Sebelum melaksanakan pembelajaran peneliti dan kolaborator berdiskusi mengenai rencana pelaksanaan pembelajaran (RPP) yang akan diterapkan ketika proses belajar mengajar, kemudian RPP disusun bersama-sama antara peneliti dan kolaborator. RPP yang telah disusun kemudian dianalisis dengan alat penilaian kemampuan guru dalam perencanaan pembelajaran. Aspek yang diamati dalam alat penilaian kemampuan guru dalam perencanaan pembelajaran terdiri dari 18 aspek. Hasil pengamatan terhadap perencanaan pembelajaran adalah: (1) penilaian kemampuan guru dalam merencanakan pembelajaran pada siklus 1 dapat disimpulkan bahwa pada tahap penilaian dengan aspek kategori sangat baik terdapat 4 kriteria, kategori baik terdapat 9 kriteria dan kategori cukup terdapat 5 kriteria dengan persentase hasil keseluruhan (78,89\%); (2) penilaian kemampuan guru dalam merencanakan pembelajaran pada siklus 2 pada aspek kategori sangat baik terdapat 7 kriteria, dan kategori baik terdapat 11 kriteria dengan presentase hasil keseluruhan $(87,78 \%)$.

\section{Tindakan (acting)}

Tindakan penelitian dilakukan dalam dua kali pertemuan. Siklus 1 pertemuan pertama dilaksanakan hari Senin, 11 April 2016 dan pertemuan kedua dilaksanakan hari Rabu, 13 April 2016. Siklus 2 pertemuan pertama dilaksanakan pada hari Senin 25 April, dan pertemuan kedua dilaksanakan pada hari Rabu, 27 April 2016. Kemampuan guru dalam melaksanakan pembelajaran mengubah teks wawancara menjadi narasi menggunakan model kooperatif tipe think talk write pada siklus 1 pertemuan pertama terdiri dari 33 aspek dan pertemuan kedua terdiri dari 32 aspek yang dinilai. Hasil pengamatan terhadap pelaksanaan pembelajaran pada siklus 1 dan siklus dua adalah: (1) berdasarkan data yang telah dianalisis didapat hasil pengamatan terhadap kemampuan guru dalam melaksanaan pembelajaran mengubah teks wawancara menjadi narasi menggunakan model kooperatif tipe think talk write siklus 1 pertemuan pertama terdapat 7 aspek berkategori sangat baik, 16 aspek berkategori baik, dan 10 aspek berkategori cukup, dari 33 aspek yang dinilai dengan presentasse keseluruhan $(78,18 \%)$. Pengamatan terhadap kemampuan guru dalam melaksanakan pembelajaran siklus 1 pertemuan kedua dengan rincian 6 aspek mendapatkan kriteria sangat baik, 19 aspek mendapatkan kriteria baik, dan 7 aspek mendapatkan kriteria cukup dari 32 aspek yang dinilai dengan persentase $(79,37 \%)$. Jadi berdasarkan pertemuan pertama dan kedua didapatlah hasil rata-rata APKG 2 siklus 1 yakni (78,77\%); (2) berdasarkan data yang telah dianalisis didapat hasil pengamatan terhadap kemampuan guru dalam melaksanaan pembelajaran mengubah teks wawancara menjadi narasi menggunakan model kooperatif tipe think talk write siklus 2 pertemuan pertama terdapat 13 aspek berkategori sangat baik, dan 20 aspek berkategori baik, dengan persentasse keseluruhan $(87,89 \%)$. Pengamatan terhadap kemampuan guru dalam melaksanakan pembelajaran siklus 2 pertemuan kedua dengan rincian 15 aspek mendapatkan kriteria sangat baik, dan 17 aspek mendapatkan kriteria baik, dari 32 aspek yang dinilai. Secara keseluruhan mendapatkan hasil persentase $(89,37 \%)$. Jadi berdasarkan pertemuan pertama dan kedua didapatlah hasil rata-rata APKG 2 siklus 2 yakni $(88,63 \%)$. Secara keseluruhan kemampuan guru melaksanakan pembelajaran pada siklus 2 pertemuan pertama dan kedua sudah sangat baik.

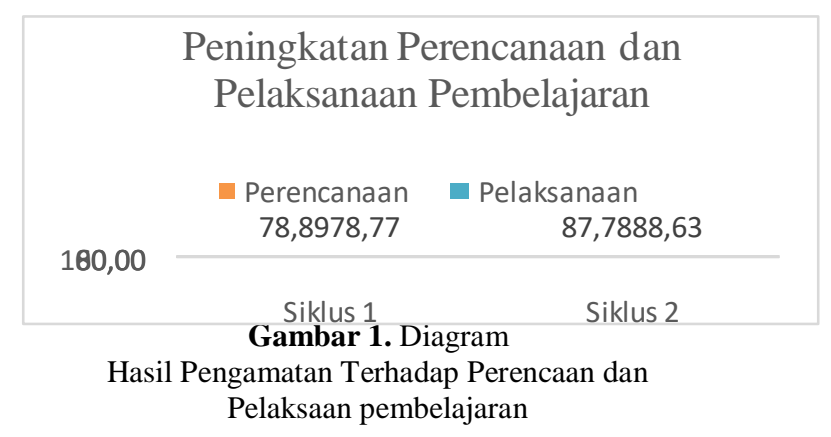




\section{Pengamatan (observation)}

Peneliti melakukan pengamatan dengan mengamati dan mencatat kejadian-kejadian selama proses pembelajaran menggunakan pedoman observasi yang telah dipersiapkan. Hasil pengamatan siklus 1 sebagai berikut: (1) pengamatan terhadap sikap siswa, hasil pengamatan peneliti terhadap sikap siswa pada kategori kategori sangat baik mencapai $11,87 \%$. Kategori baik mencapai 50\% dan cukup mencapai $15,37 \%$. Jadi pada siklus 1 nilai rata-rata sikap siswa (77,24\%); (2) pengamatan terhadap aktivitas siswa, hasil pengamatan peneliti terhadap aktivitas siswa pada kategori sangat baik mencapai $13,28 \%$. Kategori baik mencapai $48,75 \%$ dan cukup mencapai $15,46 \%$. Jadi jumlah rata-rata aktivitas siswa pada siklus 1 sebesar $(77,49 \%)$. Hasil pengamatan pada siklus 2 sebagai berikut: (1) pengamatan terhadap sikap siswa hasil pengamatan peneliti terhadap sikap siswa pada kategori kategori sangat baik mencapai $31,87 \%$ dan kategori baik mencapai $54,5 \%$. Jadi rata-rata jumlah sikap siswa pada siklus 2 mencapai $(86,37 \%)$; (2) pengamatan terhadap aktivitas siswa, hasil pengamatan peneliti terhadap aktivitas siswa Pada kategori sangat baik mencapai $39,06 \%$ dan kategori baik mencapai 48,75. Jadi rata-rata jumlah aktivitas siswa pada siklus 2 mencapai $(87,81 \%)$.

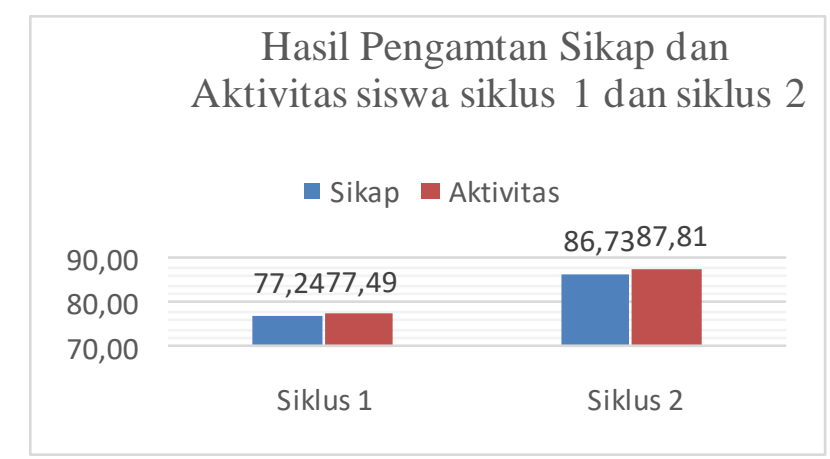

Gambar 2. Diagram Hasil Pengamatan terhadap Sikap dan Aktivitas Siswa

\section{Refleksi (Reflecting)}

Kegiatan refleksi siklus 1 dilakukan pada hari Kamis, 14 April 2016 dan siklus 2 pada hari Kamis, 28 April 2016. Refleksi merupakan tindak lanjut dari hasil pengamatan. Peneliti dan kolaborator melakukan refleksi pada perencanaan, pelaksanaan pembelajaran dan proses pembelajaran. Adapun hasil refleksi pada siklus 1 adalah sebagai berikut: (1) refleksi terhadap perencanaan pembelajaran, adapun hal-hal yang perlu direfleksi diantaranya adalah: (a) mengembangkan materi pembelajaran yang kurang sesuai dengan karakteristik siswa, sebaiknya mengembangkan materi pembelajaran dengan baik disesuaikan dengan karakteristik siswa; (b) pembagian waktu pembelajaran masih kurang baik dan kurang jelas, sebaiknya pembagian waktu pada setiap langkah pembelajaran lebih direncanakan lagi agar lebih jelas dan pembelajaran akan lebih efektif; (c) pemilihan sumber dan media pembelajaran masih kurang menarik perhatian siswa, sebaiknya pada pemilihan sumber dan media pembelajaran harus sesuai dengan tujuan pembelajaran dan karakteristik siswa di kelas; (2) refleksi terhadap pelaksanaan pembelajaran, masih ada hal-hal yang perlu diperbaiki di dalam pelaksanaan pembelajaran pada siklus 1 diantaranya adalah: (a) guru kurang memotivasi siswa, sebaiknya guru lebih memotivasi siswa untuk menumbuhkan rasa ingin tahu dan minat belajar siswa; (b) proses pembelajaran belum sesuai dengan alokasi waktu, sebaiknya guru menggunakan alokasi waktu seefektif mungkin agar pembelajaran dapat berjalan dengan baik; (c) guru kurang mampu menggunakan sumber dan media pembelajaran serta belum mampu menggunakan bahasa tubuh yang baik, sebaiknya guru memperhatiakan penggunaan sumber dan media pembelajaran serta bahasa tubuh agar pembelajaran bisa lebih menarik perhatian siswa; (3) refleksi terhadap sikap siswa dalam pembelajaran mengubah teks wawancara menjadi narasi menggunakan model kooperatif tipe think talk write siklus 1 masih terdapat siswa yang kurang berperan secara positif ketika proses pembelajaran seperti ma sih berbicara dengan temannya pada saat guru menjelaskan, sebaiknya guru lebih memperhatikan siswa yang kurang berperan positif ini agar pembelajaran selanjutnya dapat berjalan dengan efektif; (4) refleksi terhadap aktivitas siswa dalam pembelajaran mengubah teks wawancara menjadi narasi menggunakan model kooperatif tipe think talk write siklus 1 masih terdapat siswa yang kurang berperan aktif ketika proses pembelajaran seperti masih berbicara tidak sesuai dengan topik pada saat berdiskusi, masih kesulitan saat mengkonstruksi sendiri hasil diskusi. Sebaiknya guru lebih memperhatikan dan mengarahkan siswa yang kurang berperan aktif ini agar pembelajaran selanjutnya siswa dapat termotivasi dan pembelajaran dapat berjalan dengan efektif dalam pembelajaran mengubah teks wawancara menjadi narasi menggunakan model kooperatif tipe think talk write siklus 1 masih terdapat siswa yang kurang berperan aktif ketika proses pembelajaran seperti masih berbicara tidak sesuai dengan topik pada saat berdiskusi, masih kesulitan saat mengkonstruksi sendiri hasil diskusi. Sebaiknya guru lebih memperhatikan dan mengarahkan siswa yang kurang berperan aktif ini agar pembelajaran selanjutnya siswa dapat termotivasi dan pembelajaran dapat berjalan dengan efektif.

Adapun hasil refleksi pada siklus 2 adalah sebagai berikut: (1) refleksi terhadap perencanaan pembelajaran sebagian besar aspek yang dinilai sangat baik, sebaiknya pertahankan dan kembangkan pembelajaran yang sudah dibuat; (2) refleksi terhadap pelaksanaan pembelajaran, secara keseluruhan kemampuan guru melaksanakan pembelajaran pada siklus 2 pertemuan pertama dan kedua sudah sangat baik, sebaiknya lebih dikembangkan dan ditingkatkan lagi dalam melaksanakan pembelajaran agar proses pembelajaran menjadi lebih efektif, aktif dan inovatif, dan pertahankan agar proses pembelajaran menjadi lebih baik; (3) refleksiterhadapsikapsiswa, siswa sudah berperan secara positif dan secara kesuluruhan pembelajaran sudah berjalan dengan efektif; (4) refleksiterhadapaktivitassiswa, 
siswa sudah berperan aktif dan pembelajaran sudah bejalan efektif.

\section{Hasil Tes Pembelajaran Mengubah Teks Wawancara Menjadi Narasi}

Hasil siswa dalam pembelajaran mengubah teks wawancara menjadi narasi menggunakan model kooperatif tipe think talk write dapat dilihat dari hasil tes. Berikut hasil tes siklus 1 dan siklus 2 yang di perjelas pada diagram di bawah ini.

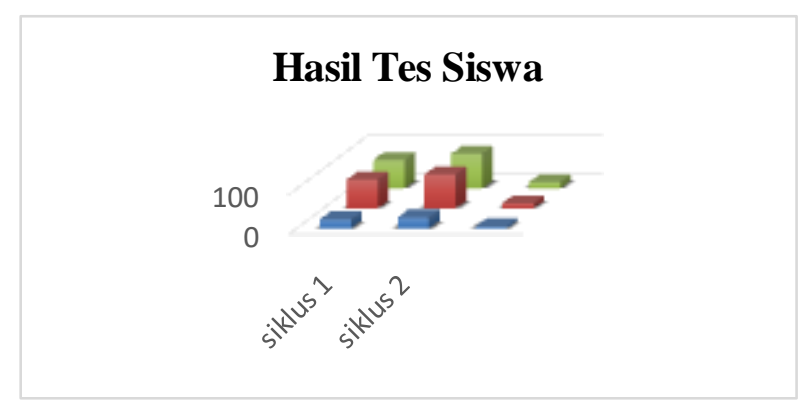

Diagram 3. Hasil Tes Siswa Mengubah Teks Wawancara Menjadi Narasi Menggunakan Model Kooperatif Tipe Think Talk Write Siklus 1 dan Siklus 2

Berdasarkan diagram di atas dapat diketahui bahwa pada tes pembelajaran mengubah teks wawancara menjadi narasi menggunakan model kooperatif tipe think talk write pada siklus 1 dengan rata-rata $72,5 \%$ dan siklus 2 dengan rata-rata $85,62 \%$, hal ini menunjukkan peningkatan nilai siswa sebesar $(13,12 \%)$. Jumlah siswa tuntas pada Siklus 1 sebanyak 23 orang dengan persentase ketuntasan $71,87 \%$ dan siklus 2 sebanyak 28 orang dengan persentase ketuntasan $87,5 \%$. Hal ini menunjukkan peningkatan persentase ketuntasan sebesar $(15,63 \%)$.

\section{SIMPULAN DAN SARAN}

\section{SIMPULAN}

Berdasarkan hasil penelitian yang dilakukan peneliti di SMP Negeri 11 Singkawang keterampilan siswa dalam mengubah teks wawancara menjadi narasi, dapat disimpulkan bahwa dalam penelitian ini mengalami peningkatan di setiap siklusnya, dibuktikan dengan beberapa hal diantaranya sebagai berikut: (1) Perencanaan pembelajaran pada siklus I mencapai $78,89 \%$ dengan kategori baik dan pada siklus II mencapai $87,78 \%$ dengan kategori sangat baik mengalami peningkatan sebesar (8,89\%); (2) Pelaksanaan pembelajaran pada siklus I mencapai $78,77 \%$ dengan kategori baik dan pada siklus II mencapai $88,63 \%$ dengan kategori sangat baik mengalami peningkatan sebesar $(9,86 \%)$; (3) Hasil Pada siklus I ratarata siswa 72,5 dan pada siklus II mencapai 85,62 mengalami peningkatan sebesar 13,12\%. Sedangkan persentase ketuntasan siswa pada siklus I mencapai $71,87 \%$ dan pada siklus II mencapai $87,5 \%$ mengalami peningkatan sebesar $(15,63 \%)$.

SARAN

Saran yang disampaikan peneliti berdasarkan hasil penelitian sebagai berikut:(1) guru mata pelajaran bahasa Indonesia dapat menggunakan model kooperatif tipe think talk write untuk meningkatkan kemampuan mengubah teks wawancara menjadi narasi dan memiliki kemampuan mengajar dengan baik serta dapat mengaplikasikan model think talk write ini dengan baik agar tujuan pembelajaran dapat tercapai; (2) guru hendaknya selalu berupaya meningkatkan pengetahuan dan kemampuan merancang strategi pembelajaran yang tepat dan inovatif, baik dari segi model, media, pendekatan dan rancangan, sehingga proses dan hasil pembelajaran sesuai dengan tujuan yang diharapkan; (3) sebaiknya siswa dapat mengembangkan ide dan bekerjasama dalam proses pembelajaran dengan model kooperatif tipe think talk write agar prestasi belajar mereka dapat meningkat serta dapat melatih mereka dalam kegiatan menulis

\section{DAFTAR PUSTAKA}

[1] Abdurrahman, Mulyono. 1999. Pendidikan bagi Anak Berkesulitan Belajar. Jakarta: Rineka Cipta.

[2] Akhadiah, Sabarti. 1998. Menulis I. Jakarta: Universitas Terbuka.

[3] Anindyarini, Atikah dan Ningsih Sri. 2008. Bahasa Indonesia untuk SMP/MTs Kelas VII. Jakarta: Pusat Perbukuan, Dapertemen Pendidikan Nasional.

[4] Asmara, Uray Husna. 2011. Penulisan Karya Ilmiah. Pontianak. Faruna Bahagia Pontianak.

[5] Huda, Miftahul. 2014. Model-model Pengajaran dan Pembelajaran. Yogyakarta: Pustaka Pelajar.

[6] Istarani, Muhammad Ridwan. 2014. 50 Tipe Pembelajaran Kooperatif. Medan: CV. Media Persada.

[7] Keraf, Gorys. 2010. Argumentasi dan Narasi. Jakarta: PT. Gramedia Pustaka

[8] Saddhono, Kundharu dan Slamet. 2012. Meningkatkan Keterampilan Berbahasa Indonesia (Teori dan Aplikasi). Bandung: Karya Putra Darwanti.

[9] Suriamiharja, A. dkk. (1997). Petunjuk Praktis Menulis. Departemen Pendidikan dan Kebudayaan Direktorat Jendral Pendidikan Dasar dan Menengah Bagian Proyek Penataran Guru SLTP Setara D-III.

[10] Tarigan, Henry Guntur. 2008. Menulis Sebagai Suatu Keterampilan Berbahasa. Bandung: Angkasa. 